Research Notes

\title{
Islamization of Knowledge with Special Reference to Political Science
}

\author{
AbdulHamid AbuSulayman*
}

\section{Introduction}

This paper discusses the crisis of thought prevailing in the Muslim world today, and considers it a fundamental cause of the current degeneration, decadence and backwardness of the "Ummah." Hopefully, it also highlights the role the International Institute of Islamic Thought will play in counteracting and ultimately overcoming the crisis.

Such a theme inevitably brings the Islamic concept of knowledge to the forefront. First of all it must be decided whether such an investigation is merely an intellectual extravanganza or whether there is actually a real issue that deserves investigating. No one possessing insight into the condition of the Ummah can fail to realize that there exists a crisis involving a number of issues and complex dimensions. These issues are:

1. The backwardness of the Ummah.

2. The weakness of the Ummah.

3. The intellectual stagnation of the Ummah.

4. The absence of Ijtihad in the Ummah.

5. The absence of cultural progress in the Ummah.

6. The Ummah's losing touch with the basic norms of Islamic civilization.

All these issues indicate, in one way or the other, the intellectual crisis prevailing in the Muslim World. There is no doubt that this crisis is the cause and, at the same time, evidence of the decadence and impotence of the Ummah, and prevents it from anything significant to the culture and civilization of the modern world. This incapability is futher exacerbated by the frequency of political, economic and military crises.

*Dr. AbdulHamid AbuSulayman is the Director General of the International Institute of Islamic Thought and the President of The Association of Muslim Social Scientists. He has his Ph.D. in International Relations from the University of Pennsylvania, Philadelphia. He served as Assistant Professor and the head of the Department of Political Science at the King Saud University, Riyadh, Saudi Arabia. 
Whether we discuss the problem of Ijtihad in Islamic thought; the causes of the disparity between our past and our present; the disparity between Islamic values and the actions of Muslims; or the insignificance and marginality of the presence of the Islamic character, we inevitably find that the crisis in the Ummah's conception of knowledge is the sole cause of the state of decadence of our Ummah, and its resolution is essential for any clarity of vision, effective reforms and redirection of the Ummah.

It is a fact that despite its backwardness, the Ummah has never been short of natural resources, human potentiality or historical perspective. Nor has it been deficient in ethical and moral values. It still possesses the time-honoured principles and values revealed in the Qur'an and the Hadith. Furthermore, the Ummah has made limited and short-lived attempts in Morocco, Sudan, the Arabian Peninsula, the Indian Sub-continent and other Muslim countries to salvage itself from its decadent and backward situation along the perspectives envisaged by traditional thinking. But all those attempts have been confined to Muslims leading a nomadic life in the remote desert areas, and have failed to influence or attract the urban population. They have failed to counter the distracted and diseased forces of the metropolitan cities which represent not only the impotence of the Ummah but are also hostile to its cultural, intellectual and organizational progress.

Whenever the Ummah has tried to adopt foreign tactics, it has undergone bitter experiences, such as those which took place in Turkey during the reign of Saleem III and in Egypt ever since the reign of Muhammad Ali. The Turkish experience is the oldest and the most inclusive. These countries tried to imitate the technical, organizational and intellectual styles of foreign countries, basing their political constitutions on concepts such as nationalism and secularism which they imposed through state intervention. But the imitative experiments have ended in miserable failures as can be seen by the utter helplessness and deteriorating conditions of Turkey and Egypt.

This leads us to the obvious conclusion that the imitation of foreign styles is just as fruitless as the traditional imitation of past perspectives. Both of them have failed to achieve the objectives set up for the Ummah. It is imperative that reconstruction requires an original redefining of the intellectual and socio-cultural potentialities of the Ummah on the basis of its values, principles, and historical perspectives. A redefinition of knowledge should be the starting point for such reconstruction.

\section{How the Crisis of Knowledge Began}

We must realize that knowledge was the basic cause of the progress and development of the Ummah. At its very beginning Islam managed to build up the structure and character of the Ummah on the firm basis of knowledge acquired through its proper sources, namely: divine revelation and active 
reason. Divine guidance endowed the Prophet Muhammad with a clarity of vision that enabled him to weave an exemplary pattern of a life. The Qur'an explicitly encourages the gaining of knowledge and education as well as the value of learning from experience. The first revelation calls upon the prophet and humanity to seek education and acquire knowledge in accordance with the divine guidance:

\section{Read in the Name of thy Lord and Cherisher. . [Surah XCVII, 1]}

There was nobody more capable of leadership than the Prophet Muhammad. Nonetheless, he used to consult his companions on almost all matters, which enabled him to excel in directing the individual and collective affairs of the Muslims in the most efficient and comprehensive manner during both war and peace. The extent of that strength can be gauged by the failure of the West to counter the storming attack of the Uthmanis until it started the intellectual and cultural revolution which came to be known as the age of enlightenment. Through that enlightenment the western nations reorganized their forces, defeated the Muslims and emerged as formidable entities.

On the other hand, when the tables had turned and the balance of power had shifted to the west, the reaction of the Muslims, which was essentially political and military, failed to make use of a spirit of sacrifice and sincerity that would have enabled the Muslims to defend not only their homeland but their values as well. Backward and lacking confidence in its moral and spiritual values, the Ummah attempted to counter the western power, but this resulted only in bloodshed, economic disorder and general deterioration in every walk of life. An analysis of the relations of any two Muslim countries reveals tendencies which sabotage the overall interests of Muslims.

With the passage of time, knowledge deteriorated and Islamic character weakened. In short, there followed a steady downfall in cultural and intellectual domains despite the fact that the spirit of sacrifice and sincerity persisted in devout Muslims. Virtues and qualities such as competence, energy, initiative, seriousness, creativity, wisdom, etc., which had characterized the early "emergency" phase of the Ummah, and which had enabled the Muslims not only to defeat the forces of anarchy, disruption and barbarism but also to win for them respect and admiration all over the world, have disappeared. One wonders how the virtues that enabled the Muslims to establish a matchless civilization has disappeared; how the energy and resourcefulness has been dissipated; how the Islamic character has degenerated; and how is it that the whole Islamic system has disintegrated?

\section{The Split in Leadership}

The strength of the Ummah resided in the Caliphate system established by the Prophet in Madinah. But during the process of local defence and outside conquest, tribal men infiltrated into the army. The habits of thought and up- 
bringing of these men were far below the standard of the Companions, who had built the state in Madinah. Lacking the spirit that motivated the caliphs, these tribal men sought to secure their position by establishing a new system which was a mixture of the tribal notions prevailing in the pre-Islamic state of ignorance and the half-cherished Islamic notions acquired after the rise of Islam. That hybrid system was the starting point of the deterioration and ultimate disintegration.

Although the ruling body was guided by tribal norms, the people in the Hijaz who represented the true Islamic consciousness refused to accept the new tribal order and revolted against it using physical force. This encounter led to a series of internal wars led by pious personalities such as al Hussein Ibn Ali, Abdullah Ibn al Zubair, Zaid Ibn Ali, and others.

But the spirit of revolt remained confined to the Hijaz for two reasons. First of all, the newly converted Muslim populace was not well acquainted with the teachings of Islam. Second, as more and more people embraced Islam, they brought with them their traditional, pre-Islamic customs and habits. Furthermore, a separation between religion and politics gradually isolated the intellectual leadership. The religious scholars who always represented the opposition to the political authorities, were forced to withdraw as far as possible from the scuffles and struggles of politics. Thus Imam Abu Hanifa died in prison refusing to accept a high judicial post. Imam Malik Ibn Anas was physically tortured because he gave a verdict on compulsory divorce against the wishes of the rulers. Imam al Shafi'i was forced to immigrate from Baghdad to Egypt.

This schism of the intellectual and political leadership initiated the evils of deceit, ignorance and arrogance which crippled the structure of the Ummah. Religious thought was confined to the level of abstraction, and was not allowed to function in regulating practice and evaluating experience and experiment. Thus the very concept of the Ummah and its leadership began to wither.

This withering was accelerated by the theoretical, unsystematic manner of Islamic thinking which made the Ummah lose touch with its attitudes, needs and priorities for progress. On the other hand, the deviation of the political leadership and the measures it adopted to silence all opposition made the task of the intellectual leaders more difficult than ever before. Mutual distrust was the rule rather than the exception. The religious personalities became suspicious and sceptical of any initiative taken by the politicians irrespective of its validity. This sceptism created an uncompromising attitude in the intellectual leadership; a rigidity that sealed up the avenues of Ijtihad in attempt to protect the teachings ordained in the Qur'an and the Hadith, from any deviations threatening to their authenticity. Such a rigidity is understandable, but it must be admitted that the intellectual leaders failed to foresee the dangers of confining 
and concentrating their efforts on abstract thinking.

There was another conflict regarding the application of the teachings of Islam in every day life. This conflict impoverished the intellectual activities of the Muslims and consequently enfeebled the character of Muslim culture and civilization. During the early days of Islam islamic ideology was marked by a spirit of initiative, fruitful interaction, resourcefulness, competence, and vigour. It was a time that fostered intellectual courage and moral uprightness. That quality kept the spirit of Islam fully alive; its aims and objectives clearly defined, expounded and pronounced. It started as early as the time of Abu Bakr when he clarified the misconceptions lurking in the heads of the tribal men who had embraced Islam. On the basis of that clarification Abu Bakr obliged the tribal men to pay Zakat and pledge allegiance to the caliph. Similarly, Umar resorted to Ijtihad in order to clarify issues regarding kharaj and divorce. So did Ali Ibn Abu Talib on various issues. Admittedly, the period of the first caliphs was a natural continuation of the time of the Prophet. Nonetheless, many aspects of their era, especially in the field of administration, clearly indicate their depth of insight into, and strict adherence to the Shariah to settle the problems they encountered.

The phenomenon of technical, abstract and academic intellectuality was not known then. It alarmingly emerged when the gulf widened between the intellectual and politial leadership. It is no wonder that this tendency dealt a blow to the true spirit of Islamic legislation and politics. And with the passage of time, Islamic thought became lifeless.

During the reign of the Righteous Caliphs, the leaders struck a harmonious balance between religion and politics. The caliphs' faith and practices fully adhered to Islamic values and objectives and consequently won the confidence of their subjects. The fruits of their experience and thought was utilized for the welfare of the Ummah. There was no dichotomy or conflict between the temporal and the spiritual. The caliphs firmly believed that human reason was fallible but could be utilized within the limits set by divine revelation.

But when the leadership lost its strength, the gulf between religion and politics widened, and there followed more and more dependence upon reason. At the same time, the Muslim's conquest of other nations and the contact resulting thereof brought about an intellectual and cultural pomposity which lacked seriousness, especially amongst the court and political circles. As a result, academic pursuits did not adhere strictly to the spirit and objectives of Islam. This tendency made itself conspiciously evident in the popularity of rhetoric, philosophical and theological discussions, and sophistry. Those in authority made the situation even worse by patronizing philosophers, orators and factioneers. Such unwholesome favoritism led to the emergence of extremist movements such as the Ikhwan-al-Safa, the Batinis and the Sophists.

It goes without saying that these intellectual pursuits were not governed 
by the spirit of Islam. The clearest instance was the indulgence in discussing the nature of God's transcedence. Such a theme has no place in Islamic thought because the Qur'an explicitly pronounces: "He (Allah) begets not, nor is $\mathrm{He}$ begotten and ther is none like unto Him.” [Sura CXII, 3-4].

The heretical nature of the futile and unbridled rationalism of the age outraged eminent Muslim scholars such as Hujah al Islam Abu Hamid al Ghazali and Shaikh al Islam Taqi al Din Ahmed Ibn Taimiya, who spent their lives exposing the deviations introduced by these sects.

The struggle against the infiltration of foreign thought and culture proved fruitless and, as a result, Muslim scholars grew more and more sceptical and hostile towards the manifestations of reason in philosophical discourses. Heneforth academic pursuits became more inclined towards explicating Shariah texts, the Arabic language and jurisprudence. This tendency led to more concentration on second-rate thought, authentication of texts, and the compiling of glossaries and historical trivialties. The result was a state of intellectual incompetence which closed off the gates of Ijtihad and promoted concentration on textual studies in a repetitious way and from a theoretical view point only.

\section{THE PRESENT CRISIS IN ISLAMIC THOUGHT}

The present crisis in Islamic thought is more alarming than ever before. Admittedly, the long-standing isolation previously mentioned has resulted in incompetence and superficiality of thought, but it is not the main cause of the crisis. Much more to the point is the inability of our thinkers to measure the extent to change that has taken place in the realm of knowledge, culture and civilization in the modern world. There is also a parallel inability to locate the points of strength in the sources of Islamic knowledge and to learn from past experience.

As a result of this situation people have felt the urgent need for restoring Ijtihad. This call has brought about conflicting reactions. Some have argued that it should be restored even if it has been revoked. Nonetheless, Ijtiahd has remained sealed up and consequently thought has remained inept. However here and there have emerged occasional glimpses of systematic thought which could have defined the direction of knowledge, thought and culture but which have failed to mature into proper schools of thought because they depended so heavily upon the characters of the men who initiated them.

But redefinition and redirection of thought require a radical change in our attitude towards what the human mind can and cannot do. This is essential because the main cause of the crisis of knowledge lies in our understanding of the sources of knowledge, which has confused our attitude towards reason. The crisis also lies in the nature of our Islamic methods of research, which 
are confined to textual studies of language, traditions and orthodox jurisprudence. These two attitudes are manifested in our tendency to regard the faqih (jurist) in the historical sense of one who is capable of resolving the crisis of thought, culture, and knowledge. The jurist is expected to use Ijtihad in order to provide solutions and alternatives which the Ummah might use to counter its enemies.

\section{The Basis for Reform}

If we desire to reform our knowledge, culture and civilization; steer the Islamic movement in the right direction; and invigorate the Muslim character; formulate plans for Islamic dawah (preaching)l; we must initiate reform in each of the following areas:

Firstly, we must rectify the relationship between divine revelation and reason as manifested in our lines of thinking.

Secondly, we must redefine knowledge in a way that leaves no ambiguity about concepts such as Ijtihad and roles such as that of the faqih. In this respect, there must be a clear-cut distinction drawn between Ijtihad and Ifta in the light of the current trends in Islamic thought.

Thirdly, we must reorganize and reorientate the methodology of Islamic education and instruction in order to put an end to the confused dualism that divides knowledge into intellectual, social, religious and legal categories, thereby creating further dualism in the leadership.

\section{RECTIFYING THE RELATIONSHIP BETWEEN REVELATION AND REASON}

It is quite obvious that the position of superiority achieved by the West in the realm of knowledge and thought is purely intellectual and has nothing to do with divine revelation. In spite of the tremendous achievements reached by Western thought in the experimental fields, Western scholars cannot deny the maladjustment and imbalance in the Western society. This is caused by the inapplicability of empirical methods to conflicting societal welfare on the one hand and the pursuance of personal desires and interests on the other. This is so because human reason alone is incapable of attaining the ultimate truth about and full understanding of what is desirable for humanity in this life and in the life hereafter. This predicament lies in the fact that Western civilization is lost in so many haphazard and contradictory theories that it is unable to arrive at one single theory or confidently resolve any problem. Islamic sources of knowledge on the other hand are divine revelation and reason. There is no problem in saying that revelation and reason are the sources of knowledge in Islam, but the problem lies in defining and giving a concrete 
shape to the relationship between the two.

Such a dichotomy has no place in Islam because divine revelation embodies the objectives of human reason and prescribes checks and controls against intellectual deviation and spiritual perversion. Nonetheless, it is important for Muslims to realize that divine revelation itself might be subject to misunderstanding and misinterpretation. This is both a problem and a challenge which Muslims have to face because inadequate use of the intellectual faculties in interpreting Islamic knowledge not only jeopardizes sound judgement but may also thwart the revelation itself. The fears about the negative results of a perverted misuse of the intellectual faculties, which have beset the lives of non-Muslims, should not discourage Muslims from the application of reason. Should that be the case, Muslims will not only lose the golden opportunity that divine revelation offers with regards to defining the role of the mind in pursuing the purpose of existence but might also misunderstand divine revelation, thereby wreaking further damage.

One can cite countless examples of the Ummah's practices which result from ignorance, inexperience and a lack of the use of systematic reasoning. Such deficiencies not infrequently lead the Ulama to deceptive and unreasonable conclusions or adopting unfortunate attitudes which not only cause more harm than good but can also alienate Muslims and non-Muslims alike from the cause of God. This is the reason why it has to be emphasized that the crisis lies in the perception of the relationship between revelation and reason. This is to say that the two should be harmoniously synchronized that they are inextricably bound with one another. Revelation cannot function in the absence of a rational mind, and the rational mind is not worthy of recognition or respect if it strays from pure and simple revelation. Therefore, it can be concluded that the core of the problem does not lie in the necessity for or the lack of the mental faculties, but in the manner in which they are made to function as well as the quality of their functioning.

The mind is an indespensible source of knowledge, thought and culture, but it must be used cautiously within the defined purpose of existence and the framework of revelation in a disciplined and committed spirit which seeks to enrich rather than enfeeble Islamic thought. In this way we can avoid the haphazard practices and false assumptions which have disturbed and occasionally distorted our history.

This leads me to conclude with a few, emphatic statements. It is un-Islamic to indulge in any investigation or express one's opinion on any matter if one is uncertain of one's knowledge in this regard. Ignorance cannot enlighten anything or anybody. Conclusions reached through ignorance are usually extravagant and excessive. Islam enjoins us to refrain from extravagance and excessiveness, and requires us to exercise mercy and kindness. It is equally un-Islamic to disregard the needs of Muslims and the effect of what we say 
on their behavior. It is also un-Islamic to accept the notion that we are unable to look after the affairs of Muslims as a result of an inability to apply our mental faculties properly. Last but not least, it is un-Islamic to give reins and spurs to the human mind in total ignorance of Islamic principles, ideals and values.

The following examples will clarify my point:

Firstly, the issue of pricing:

If Muslim scholars had based their thinking solely on the apparent meaning of Islamic texts when considering the pricing system, they would have prohibited controlling prices. But common sense alerted them to the problems which might result thereof. Observation and experience indicate quite clearly that the absence of a pricing system creates vices such as exploitation, fraud, and injustice to the masses. That being the case, prohibiting a pricing system would undermine the cause of Islam, which preaches justice and equality. This shows that the mind has been used advantageously and has proved capable of giving proper guidance in the light of the total spirit of Islam. By realizing the priority of justice in Islam, it has not been distracted by technical considerations from accepting a system that would put checks and controls on such transactions.

Unfortunately, those whose common sense directed them to the necessity of a pricing system failed to analyze and comprehend the phenomenon in its totality. More consideration should have been given to reconstructing the market to achieve balanced transactions. It was not enough to introduce protective measures and be content with them. Nonetheless, it has to be emphasized that it was a courageous, well-informed step clearly demonstrating the good that can be derived from purposeful application of a seriously committed Islamic line of thinking used to investigate a phenomenon cautiously and wisely within the frame-work of the fundamentals of Islam.

Secondly, purification from the saliva of the dog:

This issue has been discussed by Imam Muhammad Ibn Ismail al San'ani (1182 A.H.) in his book, Subul al Salam Sharah Bulough al Muram Min Adillat al Ahkam. He analyzed the matter on rational grounds in the light of the knowledge available to his age and came to the conclusion that the saliva of the dog is in no way more impure than many other impure things and can be cleaned by washing three times. But Islamic thinking cannot sanction rational conclusions divorced from the principles of revelation. Therefore, he concluded that in the light of the Shariah texts, the impurity caused by the saliva of the dog should be washed seven times, one of which is to be done using clay. This orthodox legislation has to be observed since there is no religious or material benefit to be derived from disregarding it. It took several centuries for human reason and knowledge to learn about various impurities such as germs and microbes which cannot be effectively cleaned away without 
washing with a continous flow of water. This shows the necessity for a wise combination of commitment to the purpose of Shariah and rational conclusions in order to analyze and prescribe the remedy for each particular issue without any obstinacy, excessiveness, or abrogation or perversion of Shariah.

It is, therefore, imperative that coordination between revealed knowledge and human reason be inculcated in our consciousness, culture, and thought. Any disparity between the two or uncertainty about their relationship represents a dangerous phenomenon which must be eradicated from Islamic thought. This will avoid haphazard, irresponsible actions and contradictory responses whenever we are faced with a complex issue for which a clear-cut answer does not exist.

\section{REDEFINING THE SCOPE OF KNOWLEDGE; THE SOURCES OF IJTIHAD; THE LIMITS OF THE JURIST; DISTINCTIONS BETWEEN IFTA'A AND IJTIHAD}

One of the mistakes made by Muslim researchers as a result of the influence of the historical approach upon their manner of thinking is that they continue to regard the orthodox jurists responsible for defining the scope of Islamic knowledge. They believe them to be capable of providing the thinking and Ijtihad necessary for reorganizing modern life. They assume that the authority of these jurists can provide a basis for activity responding to the challenges the Ummah faces and provide it with alternatives to counter hostile cultural and social organizations.

This understanding is basically wrong because it rests upon an assumption that is no longer valid in the realm of modern knowledge, i.e., the faqih possesses the necessary knowledge capable of providing Islamic alternatives through rational effort. Historically, this understanding was, to a large extent, true because the faqih was a merchant, philosopher, mathematician, physician and chemist. In addition, he was well-versed in various branches of Islamic Shariah and jurisprudence. In that capacity, he was well-equipped to direct his versatile intellectual abilities in the services of Islamic studies and in the interest of the Ummah.

However, we must realize that modern knowledge has expanded immensely and has become so complex that it is impossible for a single person to acquire a command of the multiple aspects of even one branch of knowledge. This means that the ability necessary for Ijtihad in any one of the various branches of knowledge requires specialization in and absolute mastery of that branch. In view of this multifacedness of knowledge, and the multifariousness of the fields of specialization, it is clear that Ijtihad, insights, solutions, alternatives, etc., in the domain of social and scientific knowledge cannot be pro- 
vided by the specialists in legal studies alone. Both the task and the expectation are impossible.

This is most noticeable in the case of the legislators who formulate and categorize the laws and regulations covering economics, politics, information, industry, scientific research or transformation, although it cannot be assumed with any degree of certainty that they are the masterminds of the knowledge from which the laws and regulations have been derived. In view of the achievements and progress made in the modern fields of knowledge, we urgently need economists, educationists, politicians, administrators, etc., who are well-versed in the various affairs of social life as well. Such specialists should at the same time have first hand knowledge of the Qur'an and the Sunnah, which give them proper insight into the morals, values and purpose of existence as understood in Islam and validate their activities and contributions. The positive outcome of the efforts exerted by such well-equipped specialists will be the development of the source on which legislators can draw to meet the day-to-day requirements of the Ummah and vitalize its existence. By so doing we will be able to define the place Ifta and legislature in the field of knowledge, as well as the social performance resulting thereof so that it should not be overburdened or misguided. This means that we will cause to call upon orthodox jurisits or legislators to provide the insights, orginality and answers to new, intricate problems, but proceed with an unflinching determination to keep abreast of knowledge by preparing cadres of specialists capable of living up to the expectations and requirements of the age.

The responsibility of these inter-disciplinary specialist cadres will not remain confined to a particular authority; rather it will be shared by the academic, representative and legislative bodies which make responsible pronouncements arising from the need and demands of the Ummah's social structure. This approach is necessary for enhancing the intellectual vitality of the ummah and for removing any ambiguities or anxieties from its daily practices.

\section{THE ESTABLISHMENT OF AN ISLAMIC INFRA-STRUCTURE AND SYSTEM OF EDUCATION}

Historically, the dichotomy between the political and intellectual leadership could be considered as the main cause of not only the weakness and gradual withering away of Islamic knowledge and culture, but also of the tyranny, ignorance, and despotism of the politicians. At present, as a result of the historical vacuum created by that dichotomy and the military, political, cultural and colonial Western influence, there has emerged a dualism in knowledge itself.

There exists an Islamic knowledge, limited in scope and legalistic in nature, whose influence is growing less and less with the passage of time, so much 
so that some of the so-called Islamic states dominated by secularism, dare amend, alter and pervert even family and personal laws.

There also exists an imported, secular knowledge whch dominates every aspect of life, and whose advocates respond thoughtlessly to and imitate blindly the trends and developments of the age. This secularism is perpetuated and popularized by the institutions, universities, and organizations in the various Islamic states.

The two categories of the current knowledge form a tree which is unable to grow because the first category lacks the essential causes that foster growth and the second is alien to the Muslims, their lands, goals and objectives. For this reason, when one talks about reforming and reconstructing the perspectives of Islamic knowledge and culture, one has in mind the initiation of a revival that should make them fit once again for production and growth. But that goal cannot be achieved without reconstructing and reorientating the programs of education and instruction. The hope for and the possibility of uprooting the forms of dualism at the level of leadership and knowledge lies in providing technically able and Islamically committed cadres who are wellversed in Islamic teachings, which need to be simplified and purposefully categorized.

Initially, each field of specialization must include in its curriculum a sufficient number of texts of religious knowledge which would mould and serve as a guide to the mentality of the learner. Next, it would be imperative that every aspect of the curriculum keep in view the objectives and values of the teachings of Islam in a harmoniously comprehensive manner so that the essential unity of the nature of Islamic knowledge and culture should not be lost sight of. Only then can the Ummah claim to possess knowledge that corresponds to the Islamic objectives. This approach will not leave any room for the coexistence of an Islamic university and a secular university at the same time and in the same place. There will be no room for limiting our objectives, thought and curricula by confining them to legal and linguistic studies. There will be room only for those studies which are oriented towards fulfilling the Islamic purpose of existence, abiding by its checks and controls and following an Islamic approach to the sciences and the humanities. The reorientation of education and instruction towards a purely Islamic style for the fulfillment of Islamic objectives would include methodology, professional commitment, and social involvement in accordance with what is proper for each field and is required by the Muslim Ummah.

\section{THE HISTORICAL RESEARCH METHODS AND FOUNDATIONS OF ISLAMIC THOUGHT}

Talking about the bases of reform necessarily leads to the investigation of 
the methods of research and foundations of Islamic thought in order to determine their place in the process of reform. This is necessary for a clear understanding of the relationwhip between the redefinition of knowledge and the reconstruction of its research methods on the one hand, and between the historical concept of the foundations of Islamic thought and the terms associated with it on the other.

Generally speaking the term Usul refers to the sources and research methods in Islamic thought. In view of what has already been said it seems proper that the direction of reform should begin with investigating the sources of knowledge and determining the organic relationship between them prior to considering the issue of Usul. Usul is an inclusive term comprising a variety of unrelated issues which historical circumstances caused to be grouped together. In my opinion, this lack of homogenity has become a source of confused intellectual and methodological complications. The term stands for the Qur'an, the Sunnah, qiyas (analogy) and ijam (consensus). Ijma is a legal concept comprising the consensus of the competent scholars of the Ummah with regard to legal questions which are not commented upon in the written sources. Qiyas is also one of the legitimate sources of normative legal inferences. Other elements of usul are "dharurah" (necessity), "maslaha" (need of the hour), "istishab" (association) and "istihsan" (preference), all of which are methods and regulations purporting to facilitate reaching legal inferences. This framework requires an objective, patient study which should trace its evolutionary development and the various influences leading to its present formation in order to develop it and invigorate it in a manner that would gear it up in the service of Islamic knowledge, culture and legislation.

In spite of the superficiality and at times complete unavailability of specialized studies with regard to the research methods from which thought originated in the early phase of Islam it is quite easy for us to perceive tremendous differences in the vitality, initiative, courage and perspicuity which characterize the thinkers of that generation. At the same time one cannot help noticing instances of stagnation, rigidity and trivialization which crept into Islamic research methods, particularly with regard to the concept of Ijma as understood by the exponents of Usul.

It is important to realize that the current concept of "Usul" was formulted in an earlier period and, in that capacity, it responded to the needs of that age. This means that the concept is out of date. The developments, changes and trends in the realities of Muslim life require a reframing in order to determine the amendments that have to be introduced into the research methods pertaining to the study of revelation and the pursuit of knowledge.

While instituting reform, the factors of time and place have to be given adequate consideration with regard to the influence they might have on the interpretation or amendment of each text individually, as well as the totality 
of related texts within the framework of the principles of divine guidance. For example, the traditions of the Prophet and the books on jurisprudence abound in minute details about the procedures pertaining to raising zakat, and on animal and plant production because these were the sources of wealth in the Arabian Peninsula during the life of the Prophet. That is why he had to utilize whatever sources were available to meet the needs of the poor and indigent sections of the population. We also find instances of exemption from "zakat" with regards to industry, minig, and estate property, in accordance with the condition of wealth and production at that time. But at present we find that the wealth resulting from the production of oil is historically unprecedented, and that the future of revenues from estate property and that of the nation itself depends upon industry. Such developments require careful and focal reconsideration to achieve the noble objectives of meeting the needs of the indigent and the "have-nots."

The effects of time and place must influence our methodological approach to understanding the totality of the Sunnah of the Prophet and the comprehensiveness of the instructions and plans which enabled him to find and organize the true Islamic State.

Research work, particularly on the Sunnah of the Prophet, has to be developed on similar lines. What is required is a comprehensive and detailed study of the texts pertaining to a particular issue, and establishing the relationships between the various issues in the light of the objectives formulated by the Prophet for the Muslims in Medinah and the Arabian Peninsula. A good example of such a fruitful approach was represented by a conference held by the Muslim Students Association in the United States and Canada. The proceedings of the conference have been published in the form of a book called Contemporary Aspects of Economic and Social Thinking in Islam. The participants deliberated on the issue of usury, singling out and studying patiently every relevant text focusing on how the policies which the Prophet adopted and the goals which he set for the abolition of the system of usury show his wisdom and far-reaching insight. The deliberations brought to light some texts which were hitherto quite unknown and dispelled all ambiguities.

The effect of time and place and a comprehensive study of issues in their right perspective puts special emphasis on the method of qiyas, which ensures arriving at conclusions which are not limited by time and place but are in keeping with the spirit of the Prophet's Sunnah. In addition, qiyas will put an end to the continuous disputes which advance partial and unrelated texts without any comprehensive vision of what the realities of the present time require. These disputes continue to tear the Unnah apart through the repetitious introduction of trivial issues. Furthermore, the failure of research to point out the damage to Islamic studies and the inefficiency which result from such trivilization points to their ineffectiveness. It needs to be emphasized that, 
however valid a partial issue may be, it is not necessarily the real issue. On the contrary, the conclusions arrived at may well be the exact opposite of those which might have been made if the issue had been considered in its entirety, within the context of time and place which influences and highlights both the concept itself as well as the validity of the purpose it is required to serve.

I place much hope in the reconsideration of our approach to revealed knowledge and the quest for acquired knowledge. The way to achieve this seems to lie in clarifying the role we assign to the mind to investigate, discover and verify subjects while giving due emphasis to the factors of time and place. This is the way to allow the mind to serve and be guided by revelation so that we may attain - through qiyas - a comprehensive vision with true insight into the core of our heritage, whose fundamentals and objectives are beyond the barriers of time and place. This approach will enable us to reconstruct our system of education and instruction and thereby achieve unity of knowledge and leadership.

\section{The Islamization of Political Science}

The problems facing Islamic thought are complex, but they can be best illustrated by a consideration of political science. Political science is a social field of study which, for various reasons, has not hitherto drawn the attention of Muslim scholars. Firstly, there is the historical dichotomy between the intellectual and political leadership, the adverse effect of which on the direction of Islamic studies has been dominated by technical, unsystematic methods of thought. Thirdly, these inadequate methods have failed to develop a comprehensive vision which provides solutions and alternatives which can meet the challenges confronted in the process of progress, change and construction, and which can be appropriated to the requirements of time and place.

The intellectual deficiency in this field may be illustrated by citing two examples. The issues involved here have already been posed by two eminent figures in the field of Islamic jurisprudence, but they remain unresolved because of the inadequacy of their methodology, which can be detected by any specialist in the field.

The first example comes from al Qadhi Abu al Waleed Muhammad Ibn Ahmad Ibn al Rheed as Qutubi al Andlusi. In his treatise on Islamic jurisprudence Bidayat al Mujtahid wa Nihayat al Muqtasid, this eminent scholar describes the differences of opinion among jurists over the sanctions on cutting trees during war: The confusion originated from the assumption that Abu Bakr's prohibition against cutting trees during the Ridda wars was not in conformity with the Sunnah of the Prophet who, during his campaign against the Banu al Nadhir, burnt down their date-trees. To reach a compromise for the justification of Abu Bakr's action, it is argued that: a) Abu Bakr acted in the knowledge that the prohibition was later abrogated by the Prophet and 
b) the Prophet's action was confined to the particular campaign against the Banu al Nadhir. Ibn Rushd's final comment on the literature regarding this issue is that "those who endorse the Prophet's action, in the absence of any evidence to the contrary, have to abide by his directives."

It goes without saying that it is obligatory upon every Muslim to act publicly and privately in accordance with the spirit of Shariah both in peace and war times. This caution has to be made because modern military strategies require more alertness, vigilance, initiative and dynamism than those planned and executed in distant times and at different places. This means that the requirements of the present times are essentially different from those of the past. If the foregoing instance is considered in this context, it will be clear that purely theoretical but unspecialized and unsystematic reasoning creates false issues and conclusions, and tries to resolve the inner contradictions it has created by resorting to hypothetical suppositions.

The very tendency to hunt for textual quotations when considering the nature of the stands and policies to be adopted by the leadership to counter military challenges and resolve political conflicts is in itself a kind of theoretical thinking which the leadership cannot adopt practically or consider serioursly. Objective thinking necessitates approaching and dealing with each problem in the context of its specific requirements in time and place so as to attain clarity of vision about the responsible and an unquestionable Islamic reaction demanded by the particular situation.

If we adopt such a realistic and comprehensive approach, there will be no point in making a comparison between the blockade of the Banu al Nadhir (which occured at that stage of the foundation of the State in Madinah when the Muslims were not only outnumbered, but whose very existence was threatened by the enemies who surrounded them) and the campaigns engaged in by the Muslim army despatched by Abu Bakr to conquer Iraq and Syria.

The campaign against the Banu al Nadhir took place at a time when Madinah had very little power and limited resources. Indeed, the Prophet properly realized that the deterioration of Muslim prestige in Madinah had made the whole cause vulnerable to the greatest dangers. On the other hand, the Banu al Nadhir who also enjoyed a well-established solidarity with the Jews, were able to fight out any seige, no matter how long it lasted, having a permanent supply of ground water to their orchards in Madinah on which they very much depended. Medinah's dates are particularly known for long-lasting nutritious value. From a military point of view, this made possible a prolonged seige that was bound to exhaust and incapacitate the Muslim army. Consequently, the Prophet ordered the Muslims to cut down the date trees and burn them to reduce the will of the Jews to stay in Madinah to protect and enjoy their properties. Since date trees take a long time to grow and bear fruit, the Prophet's decision put an end to the Jew's main source of food. It also ended the conflict 
in favour of the Muslims without any losses. Realizing the imminent doom that might result from this strategy, the Banu al Nadhir requested safe passage out of Medinah and permission to take with them what they could of their belongings. The true significance of the Prophet's wise strategy was demonstrated by the fact that peace, tranquility and prosperity was eventually restored in Madinah, after the forced evacuation of the Banu al Nadhir.

Abu Bakr dispatched expeditions to combat the hostile Roman and Persian empires, which threatened the very existence of Islam in the Arabian Peninusula by the stationing of some of their military forces along the Muslim borders. These armies practised all forms of atrocities, especially in Iraq and Syria where they oppressed the inhabitants, usurped their produce and possessions, and prohibited any freedom of worship that did not conform to their own faith. Consequently, with proper insight and wisdom, Abu Bakr planned to put an end to this state of violence, tyranny and oppression in a manner that would not alienate those in whose cause he had dispatched his liberating forces. In other words, he had to act in a manner that would clearly demonstrate the fundamental moral and ethical differences between the Muslims and the nonMuslims. He wanted the concepts of justice, mercy and tolerance to prevail as tangible realities in the minds of those who came in contact with the Muslims. If the liberating armies had been allowed to cut down and burn the date-trees, the consequences to the Muslims would have been disastrous. Losing their source of sustenance, the inhabitants would have sided with the old tyrants. Viewed from this angle, the validity and wisdom of Abu Bakr's action cannot be questioned. Both the Prophet's action and that of his successor were appropriate for the particular conditions that they were faced with. There is no point in forcing a text which was known to Abu Bakr and which guided him to act the way he did to pose an issue with regard to deviating from the Prophet's Sunnah. The real problem lies in our approach and in our methods of thinking.

The second example comes from the contemporary Faqih Shaikh Sayyid al Sabiq, whose writings are very popular in Islamic circles. His book Figh al Sunnah holds a high place among jurists. The book includes a chapter on Jihad wherein this eminent scholar talks about "tabyeet" - taking the enemy by night. Shaikh Sabiq considers various aspects of the subject and elaborates on the reasons that necessitate night attacks, such as fear that the enemy might resort to killing Muslim prisoners of war or totally uninvolved people in case of an open attack. He also considers the negative aspects for the Muslims such as killing innocent people whom they could not identify in the darkness. He cites many orthodox views on the matter to authenticate and justify his ultimate conclusion that "tabyeet" is permissible.

However, the problem that faces the reader who wants to have a full grasp of the subjects of "jihad," politics and war in Islam does not lie in the ap- 
propriateness of Shaikh Sabiq's material or its authentication. It lies, rather, in the failure to satisfy the expectations of the specialist, the research student, the man in authority and the common reader-each of whom comes to Sheikh Sabiq's work expecting to find an answer to the challenges he encounters in his special field. Unfortunately, he finds that both the vision and the manner of presentation are disarmingly helpless. Thus his hopes and expectatiions are dashed to the ground.

There is no doubt that "tabyeet" was an indispensible element in the ancient wars which were fought with swords and spears by soldiers usually on horseback. In those times, though it might have been difficult, it was not impossible to distinguish between one person and another, and should there be any victims, they would not exceed tens or hundreds. But modern wars do not distinguish between day or night, man or woman. Their victims are counted by thousands, in fact hundreds of thousands. The targets for destruction are chosen according to their strategic significance irrespective of who lives and works there. They can begin and end in the twinkle of an eye. In such wars, the study under discussion is totally irrelevant and useless. The pertinent problem here concerns the method of study, research, presentation, thought, and insight. In the light of the explanation of the deficiency of such a theoretical, unsystematic method of study, one would not be greatly surprised by what al Mawardi had to say in his book Al-Ahkam Al-Sultaniyyah. He argues and finally concludes that if only two persons pledged all allegiance to a prospective candidate for the caliphate, the transaction would be regarded as valid. He justifies his argument by the analogy of the validity of the marriage contract which requires only two witnesses.

\section{The Inadequacy of Islamic Political Studies}

If we realize the nature of the problems affecting Islamic thought as a result of the deficiencies of its methodology, we can easily understand the inadequacy of Islamic political studies. This short-coming appears in the limited, contradictory and naive nature of our studies despite the loftiness of the principles behind them, such as the system of the caliphate, shura, justice, brotherhood, equality, freedom, and responsibility.

It may be worthwhile to single out a few of the important problems which our processes of thought have failed to combat, thereby creating a chaos in our political perceptions and making the Ummah incapable of participating actively or exerting sufficient effort to counter the forces that threaten its very existence. There are two types of inadequacies:

1) Misconceptions about original texts and models which are the source of the Islamic vision that regulates thought and jihad.

2) The perilous, waive, mindless drive for Westernization, whose 
influence some of our intellectuals have opted for embracing concepts and systems which have distorted our thought and blurred our vision.

\section{AUTOCRACY AND DESPOTISM}

One of the most misunderstood concepts in the field of political science is the system of the caliphate. Muslim scholars consider it no more than a system of autocracy, to the extent that some intellectual leaders speak apologetically about what they call the just autocrat. Such tendencies result from the concentration of Islamic studies upon mere technical conditions such as who should be the caliph, who should be the heir, the pledge of allegiance, the obligation upon the ruler to follow Shariah, and the duty of the masses to obey him. But they fail to fathom the core of the political and organizational operation, the factors and forces affecting its structural stability, and the regulations that determine the choice and define the role of the political and social cadres which are bound with the responsibility of handing over authority from one leader to another and from one generation to the next. Equally important is the ability of these cadres to supervise the manner of decision-making, the manner in which the leadership exercises authority, and the limits it should not exceed. The urgent need for these fundamental checks and controls totally escapes the attention of the writers in this discipline as a result of what has already been discussed about the dichotomy between the intellectual and political leadership, and the lack of experience and specialization. These shortcomings have resulted in shallow thinking, unsystematic reasoning and simplistic perception, not only of the systems we are following but of history itself.

The misconceptions about the caliphate system are not baseless. Firstly the system holds a tremendous significance in Islamic thought as it vibrates with spiritual as well as historical connotations. As a result of the changes which have taken place since that distant period of time, nostalgic feelings make it difficult, even for an expert, to visualize the workings of the structure of this system.

Needless to say, the study of political systems cannot be confined to studying the official organizations, documents and regulations of government. It has to include all of the official and unofficial factors and forces which influence the system one way or the other. In the absence of such a comprehensive approach, neither the system nor its working can be understood. Unfortunately, the caliphate system does not lend itself to this kind of examination. There is only a bare minimum of officially documented information about the organizational structure of the system. This insufficiency is no fault of the system itself but a natural by-product of the primitive nature of the en- 
vironment in which the system originated. Before the rise of Islam, there was no complex system of monarchy or empire in the Arabian peninsula. It was inhabited by scattered tribes each following its own style of life. These tribes had never been united under one government before the establishment of the Muslim state which, as a result of the challenges it faced and the insufficiency of the human potential, did not pay much attention to the luxury of maintaining codified documents. Therefore, the Muslim state in Madinah under the rule of the Prophet and his companions needed to do no more than to lead the Ummah and administer the political and military affairs of the state for 23 years. It is no wonder, therefore that there is a scarcity of detailed information as to how leaders were chosen. The companions who established the state inevitably constituted the collective leadership. They knew about each other's competence and commitment to the cause of Islam. Each of them knew where he stood in relation to the Prophet and the other companions. This is why the nomination of the caliph presented no difficulty at all. The mosque provided the place where the cadres of the leadership and the public consulted with each other and settled all matters relating to the welfare of the Ummah. The common commitment to the cause of Islam which characterized the leaders as well as the members of the public made the system function smoothly.

However, the period covered by al Khulafa al Rashidun was too short for a systematic organization of the foundations on which the transition of the leadership could take place from one generation to the next in accordance with the principles outlined during the life of the Prophet or his immediate successors. This is the reason why immediately after the collapse of al Khulafa al Rashidun the fundamental qualities for the choice of a leader, such as seriousness, ability, and religious commitment gave way to tribal bias, selfinterest and power.

Therefore an examination of the system of al Khulafa al Rashidun and insight into the manner in which it functioned has to be cautious and specialized. Jumping to shallow conclusions and making sweeping generalizations about concepts such as the benevolent autocrat do more harm than good to the cause of Islam. In addition, such approaches are in direct contradiction to the Qur'an.

This leads me to the conlcusion that we have had enough of such irrational inferences. If our concern about our heritage is genuine, we must subject every aspect of that heritage to specialized and systematic study. This is all the more necessary with respect to the modelling of our political set-up on that of al Khulafa al Rashideen.

\section{The System of Shura and the Issue of al Riddah}

One of the issues arising from shortsightedness is the common misconception about the system of Shura. The issue was raised by Abu Bakr's decision 
during the Radda Wars. The argument goes that Abu Bakr made the decision to go to war against the hypocrites in spite of the opposition of Ummar and some of the other companions. The strange thing is that those who follow this line of argument cling to marginal points lifted from the text of the dialogue between Abu Bakr, who stood for the war, and the companion, who argued otherwise.

This argument is a faulty one because it fails to put the issue in its proper context. It fails to realize that the subjugation of the primitive, pagan tribes and their accommodation into the new system occasioned many divine revelations and decisions made by the Prophet. These show that accepting Islam was one thing, abiding by the regulations of the new system was quite another. This is expressly stated in the Qur'an [14/49].

Secondly, this argument fails to appreciate, or rather understand, the character of Abu Bakr, who is known for his tolerance, mercy, compassion, intelligence and sagacity. In addition, there was nothing novel in the events that led to the Riddah wars. Even during the life of the Prophet, some tribes revolted against the new system and some individuals even claimed prophethood. Names such as Musailima. Sajah and al Aswad al Anasi are well known. Well aware of this background, Abu Bakr would never have made an immature or a thoughtless decision. Those who think otherwise fail to realize the amount of time and the degree of effort needed to fathom the subtle considerations that underlie important political decisions.

A comprehensive examination of the issue reveals that it was much more than a theoretical confrontation or a quibble about words as the available studies we have want us to believe. Firstly, the issue poses important questions about the social and political reorganization of the Arabian Peninsula under a new system. Secondly, the issue involved here provides a concrete example of the problems that influence political decisions and the conditions that underline the responsibility of accepting political leadership. This is clearly shown in the confrontation between Abu Bakr as caliph and Umar as a representative of a group that did not at first understand the magnitude of the issue. Umar told Abu Bakr that he should either accept the opinion of his counsellors or leave the caliphate. Abu Bakr did not accept any of these alternatives. He stuck to his opinion with the full convinction that he was doing the right thing and argued patiently and persuasively in favour of his opinion. Eventually Umar and his supporters were able to perceive and concede Abu Bakr's viewpoint. Umar later admitted that Abu Bakr's perseverance, subtle firmness and acute intelligence left no ground for misunderstanding or ambguity. The force of the argument opened the hearts of his opponents to the truths of his convictions, and they consequently reconciled themselves to the right path. This issue amply demonstrate that the caliph had no authority over his counsellors, but it was his personal characteristics which won him their support and full 
confidence. It is pertinent to mention here that they had previously told the caliph that if they observed in him any deviation from the right path, they would straighten him out by the use of force. Their acquiescence in this particular case shows their conviction of and satisfaction with Abu Bakr's point of view.

The objective researcher will not fail to realize the significance of Shura and how it was practised during al Khulafa al Rashidun period. Mutual consultation was the rule rather than exception. There was no place for any form of despotism. Those who think otherwise are definitely shortsighted. Their failure lies in their inability to distinguish between executive and administrative matters which necessarily limit the scope of responsibility; and the major political decisions which require consultation, exchange of ideas, and a minute examination of these ideas so that the final decision will be binding to all concerned because of their conviction and satisfaction, without which success cannot be guaranteed.

\section{Un-Islamic Concepts and Terminology}

There is a great deal of confusion in Islamic studies regarding foreign systems and the political terminology used in them. This confusion is due to the researchers' insufficient knowledge of the foreign systems on the one hand, and the inadequacy of their approach on the other. These drawbacks are further augmented by thoughtlessly striving to catch up with the standards of the socalled "civilized" world. Under such pressures research is hastily conducted and consequently not only fails to achieve the desired goals but also adds to the confusion, lack of discrimination and uncertainty.

\section{Democracy and Sovereignty}

These two concepts are alien to our culture. Nonetheless, Muslim scholars have given them undue importance both as academic terms and as concepts. Some scholars go as far as arguing that they are in tune with the spirit and teachings of Islam and have to be adopted into Islamic thought and political systems.

There is no doubt that there are some apparent similarities between these concepts and the overall spirit of Islam. Unfortunately, these concepts comprise un-Islamic elements which our scholars have failed to detect. Through this failure, Islamic thought has inherited a kaleidoscipic phenomenon in which the pursuit of insignifican similarities has brought about undesirable notions which completely distort an already blurred vision.

Democracy, both as a concept and a system, has ancient roots in Western history, thought and philosophy. It does not merely signify the procedural measures of choosing political leaders. It is a natural extension of the 
materialistic philosophy that regards man as a physical entity whose value is measured in terms of the pragmatic or utilitarian sense of his usefulness to the state, society and the world. The spiritual aspect of man's existence, which is his real value, is not stressed in this system. In essence, democracy is no more than an amalgamation of individuals who, by forming a majority, assume the right and the power to propagate their thoughts and achieve their personal interests, while making minimal concessions to minorities.

This is the reason why concepts such as majority, minority, election, party system etc., are of paramount importance in Western political systems. Since these systems are based on secular foundations, the concept of justice which permeates them cannot be of real value to the individual or the society. Indeed, the systems do provide legal loopholes for the strong to gratify their personal interests at the expense of the weak.

Although al Shura aims at choosing the proper leadership, establishing checks and controls over them and arriving at decisions to be accepted, appreciated and supported by the public, it is not the same thing as democracy, which seemingly seeks to achieve similar purposes. By definition, al Shura derives from a philosophical perception which is essentially different from that of democracy. This difference lies in the notion of justice as a concrete fact of existence which man arrives at through his own nature and divine revelation, and which he endeavours to attain irrespective of his personal desires and interests. As a method, the system of Shura provides the procedure whereby Muslims sit together and deliberate upon important matters to arrive at and be bound by conclusions in the light of the philosophical concept of justice. If the issue under consideration does not concern justice but a case of prefering one to the other, there is no harm in adopting measures such as voting, abiding by the point of view of the minority, etc. The same measures could be resorted to if the discussion reached a deadlock in the absence of an authentic analogy. But even here, no decision should be taken until everybody has had the chance to express their opinion and cite relevant evidence.

Hasty decisions, insufficient investigation and blind imitation will not bring about the reform we desire. If we concentrate on the philosophical background of the concepts pertaining to this or that system, we will be able to develop insight into the nature of Islamic political systems, whose processes for arriving at and executing decisions are totally different from those of the West. Blind Westernization will not only cause us to drift away from our avowed goals but will ultimately lead to catastrophic results.

Some Muslim scholars have introduced the concept of sovereignty into Islamic thought, arguing that the pledge of loyalty confers sovereignty on the Ummah. Others disagree with this view on the grounds that since divinely revealed knowledge is the only source of the Shariah, no mortal can be vested with such powers. Thus, the term sovereignty applies to Allah alone. In my 
opinion any debate on the merits or demerits of this term with the intention of adopting or rejecting it does no service to Islamic thought. It distorts rather than clarifies the vision.

Sovereignty is a Western concept which is deeply rooted in the gradual evolution of Western systems. On all occasions it was resorted to in order to determine who should be entrusted with the responsibility of decision-making in the fields of politics and legislation. It first emerged during the confrontation between the monarchy and the feudal lords who gained power by uniting together during the emergence of the European nationalist states. Eventually the term soveriegnty was used to indicate the placing of political and legislative power in the hands of the representatives of the people. This became politically evident after the broadening of political participation and the emergence of new classes which sought to achieve the second position of influence within the competing industrial and commercial communities.

Arguments about adopting or rejecting this term clearly show not only insufficient awareness of the nature of the Islamic constitution but also the inability to distinguish between the varying levels of decision-making in Islamic systems. It is incorrect to assume that any one authority in the legislative affairs of the Ummah is absolute. Nor is it correct to assume that legislative bodies do not exist in the Muslim Ummah. To dispel any misconceptions in this regard, we have to be aware of the different legislative levels on the basis of which we can determine the fields of specialization in Muslim communities. The basic constitutional elements, the fundamental principles and values revealed in the Qur'an cannot be questioned or tampered with. They must be accepted as they are. But legislation at the level of the daily concerns of existence and to which we do not find any direct reference in the Qur'an or the Sunnah can be handled by the specialist bodies in the various sectors of the Ummah. If we reject this, how can we possibly explain Islamic practices such as "Ijtihad," "Ra'i," and "Rarjeeh." If the outcome of such efforts is not called "legislation," what else can we call it? In practice many of our differences and disputes are settled through the previously mentioned channels which neither permit confrontation over the source of the decision taken or cause enmity between the deliberating parties. There is no place for victory or defeat.

Blind imitation of Western systems ultimately leads to confusion in defining the spheres within which the various bodies conducting the affairs of the Ummah should behave in accordance with Islamic teachings. Mixing the two systems by adopting the concept of sovereignty leads either to depriving the Ummah of the power of decision-making and turning it over to an individual who behaves according to his own personal interpretation of what is right and wrong, or placing absolute authority in the hands of the Ummah irrespective of whether the structure is compatible with the spirit of Islam.

Sovereignty has no place in the framework in which the Islamic political 
structure is organized, but it does exist in the workings of the basic legislative spheres. The issue posed is not whether the source of decision-making is revealed knowledge or the Ummah. The real issue, needed for the implementation of a properly Islamic system, is a method which enables the Ummah to practice its role and authority in accordance with the true purpose and spirit of Islamic teachings. This is all the more necessary for a proper understanding of the nature of the Islamic framework, its evolution, and the challenges it has encountered since the Ummayyad period, as well as a commitment to its future.

\section{Religion, the State and the Caliphate}

In the absence of a clear-cut Islamic literature in the field of political science, Muslim scholars continue to pose the question whether Islam is a state, a religion or both. This debate entails feelings of embarrassment in Muslim scholars whenever there is a call for the restoration of the caliphate in our age. These two issues amply demonstrate the success of orientalists and hostile non-Muslims in confusing and misleading the thought of scholars.

By raising these issues our attention has been diverted from more useful engagements. Indeed, in the absence of a proper method and research, we will never attain any clarity of vision, and will continue to mistake trivial issues for important ones. Comprehensive insight into Islam reveals that it does not sanction any form of separation between religion and politics. Islam signifies that concepts such as the nature of the Creator, good and evil, the Hereafter, etc., all aim at giving proper guidance to man's behavior at the individual as well as at the social level. This point is too obvious to be elaborated dupon. But the fact remains that there are conditions which have resulted in unnecessarily prolonged and futile discussions on the preceding themes. These conditions are: the non-Muslims distorted picture of Christianity; Muslim awareness about the crisis of knowledge; Muslim dissatisfaction with the existing systems and an urgent desire to find an easy way out of the crisis. Thus enemies of Islam were able to take advantage of this situation by writing about Islam in a manner that would make the imperceptive Muslim believe that they were praising it. They would glorify it as a legacy full of indisputable divine secrets which ignore the social needs of human existence. Once that un-Islamic idea had been inculcated, they began to hammer the minds of Muslims with concepts such as mastery, racism, nationalism, secularism and communism - all of which are contrary to the pruposes, principles and values of the teachings of Islam. The end result for the Muslims is confusion, decadence and incapacity.

The issue of the caliphate is representative of a state of confusion among Muslims over Islamic ideals, values, principles and their historical application in Muslim societies. 
Generally it is extremely dificult, if not impossible, to reinstitute historical systems in their entirety. This makes the hope of re-establishing the caliphate system only a remote possiblity, especially if the system is interpreted as a practical embodiment of political organizations. This is true whether such hopes are entertained by orientalists or Muslim scholars, irrespective of the degree of accurate perception in such interpretations. It needs to be emphasized that the caliphate is no more than an Islamic term denoting the establishment of a social and political system in accordance with the teachings of Islam. In this sense the caliphate is an idea, a goal, a term signifying the nature of political systems in Islam. Any system, whatever its form, based on the requirements of time and place can be in keeping with the caliphate system provided that it adheres to the Islamic fundamentals regulating the spiritual and mundane affairs of the Ummah. No true Muslim would accept a system that is not based upon and committed to that Islamic purpose.

The caliphate system is an ideal for which every Muslim must strive. But our strife should not be clouded by transcendental or historical misconceptions. Nor should we be misled by those who have no respect for our Islamic identity. Such efforts require perserverence, determination and originality.

\section{Political Studies in Muslim Universities}

The main theme of this essay is the need for the Islamization of knowledge in general and that of political science in particular. The first prerequisite in the process of Islamization is to have a clear idea of the reality of these studies. Without going into details one could say that texts pertaining to Islamic political studies are no more than a handful of personal reflections on Islamic constitutional law, administration, biographies, and laws regulating war and peace. Despite, or perhaps because of, that narrow scope they occupy a marginal place in most academic curricula. These studies are insufficient because:

a) There are scarcely any analytical studies in the field of Islamic political thought.

b) There is no effort to trace the nature and sugnificance of issues brought about by political phenomena in Islamic history.

c) There is no attempt to distinguish between the original and alien elements, or the permanent and ephermeral elements in the system.

d) There is no clear cut Islamic definition of international relations.

e) The historical factors which actually influenced the foundations of the Ummah, its experiences and interactions with other nations have been totally ignored. 
f) The studies conducted both locally and internationally about Islamic systems of government and the lessons to be learnt from the actual application of these systems are also inadequate.

The reforms we are striving to achieve require the Islamization of knowledge in general and that of political science in particular because without proper insight into this field, the reconstruction of the Ummah and the preparation of cadres for leadership are impossible. Initially this can be done by founding research centres and holding discussions in the hope of clarifying our vision and defining our objectives on a more systematic basis. Those in charge of such activities should be specialists committed to the cause of Islam and to the welfare of the Ummah. Admittedly, the effort needed can be exacting because it requires comprehensive and systematic analysis of the legacy of Islam in all its primary and secondary sources. A great deal of editing will be needed. Subjects will have to be categorized; terms will have to be coined, modified or defined anew. A total renovation will be required.

Armed with deep insight, critical understanding and systematic analysis, we would not refrain from investigating non-Islamic knowledge or adopting new experimental methods provided that we remain conscious of the differences in background, motivation and purpose.

A great deal of time has already been wasted. Research centres and academic institutes should now take up the challenge. 